\title{
Influence of soil erosion and conservation practices on soil physical properties in Ginaberet, Ethiopia
}

\begin{abstract}
Soil erosion is one of the major factors leading to land degradation that affect the sustainability of agricultural production in Ethiopia. It resulted in severe soil fertility and agricultural production decline. In the past, it was time and financial resource consuming to predict soil erosion. At present, it is possible to use erosion-predicting models RUSLE cheaply and rapidly to interpret the soil erosion process at watershed level. Ginaberet watershed is one of the severely eroded areas in Ethiopia. The purpose of the study was to assess soil erosion and conservation practices on soil physical properties. Revised Universal Soil Loss Equation (RUSLE) under ArcGIS environment was used to predict the spatial soil loss rate. Maps of the five parameters in RUSLE, i.e., rainfall erosivity (R), soil erodibility (K), Land use/cover (C), topography (LS) and conservation practices (P) were overlaid. Based on the RUSLE analysis, the mean annual soil loss potential of the conserved area was 25.59 tons/ha/ $\mathrm{yr}$ and the non-conserved area was 30.92tons/ha/yr.
\end{abstract}

Keywords: conserved, non-conserved, soil physical property
Volume 2 Issue 6 - 2018

\author{
Yishak Yiferu,' Girma Taddese, ${ }^{2}$ Tesfaye \\ Mebrate ${ }^{2}$ \\ 'Raya University, Ethiopia \\ ${ }^{2}$ AgriCollege/Plant Science Department, Debre Birhan \\ University, Ethiopia
}
Correspondence: Girma Taddese, Agri College/Plant Science Department, Debre Birhan University, P.O. Box 445, Debre Birhan, Ethiopia,Tel +2519 ||40 6188,
Email girnataddesse@gmail.com

Received: July 25, 2018 | Published: November 09, 2018

\section{Introduction}

Soil erosion is a great worldwide factor for land degradation that leads to loss of soil properties and reducing soil productivity leading to food insufficiency. ${ }^{1}$ In the Ethiopian highlands, an annual soil loss reaches 200-300 tons/ha/yr from farm land. ${ }^{2,3}$ Unfavorable soil physical conditions resulting from erosion can reduce infiltration, encourage crusting, loss of soil fertility, deterioration of soil particle aggregation, degrade soil structure and reduce the effectiveness of root zone thereby reducing soil productivity. ${ }^{4}$ Soil erosion has a great effect on the change of soil physical properties due to the removal of the top fertile and organic matter-rich soil and the deterioration of soil structure or aggregation. ${ }^{5}$ Several studies in Ethiopia have revealed that soil erosion has become an alarming problem and the major factor affecting the sustainability of agricultural production. ${ }^{6}$ Over the last three decades, several types of soil and water conservation (SWC) practices have been experienced on different parts of Ethiopia including Amhara Region and particularly Basonawerana district. On the other hand, the absence of soil conservation practice can lead to accelerating soil erosion and affect the components of physical soil conditions significantly. ${ }^{7}$ Soil and water conservation practices have the ability to overcome the problem of soil erosion followed by improvement in soil physical properties. Wise use of soil conservation practices that are the decisive tool to maintain the productive potential of the soil help to decreasing the exposure of soil to erosion. Conservation practices can address both the processes of soil erosion and possible solutions to conserve the soil in a sustainable way. The improvement is in soil organic matter content, soil structure and its aggregate stability, water holding capacity, soil bulk density, soil porosity, and its workability. ${ }^{8}$ Similarly, low soil porosity, gravimetric soil moisture content, clay and silt proportion was revealed in the cultivated land without soil bund as compared with non-conserved land and reversely highest soil bulk density and sand fraction. ${ }^{9}$ Soil erosion has a great negative effect on the change of soil physical properties including soil structure, soil texture, soil moisture content, and soil bulk density in a long period of time.

\section{Materials and methodology}

The study was conducted in Ginaberet watershed, Ethiopia.
Geographically, the district lies at $9^{\circ} 50^{\prime \prime} \mathrm{N}$ latitude and $39^{\circ} 20^{\prime \prime} \mathrm{E}$ longitude and it covers about 1,208.17. Ginaberet watershed has an altitude range of 2906-3230m (Figure 1). It covers 215.85 ha area of land and it is situated in the Dega agro-climatic zone. Based on Andit Tid (2017) metrological station, the average annual rainfall of the watershed is $1498 \mathrm{~mm}$. The average yearly minimum and maximum temperature are 6.2 and $19^{\circ} \mathrm{C}$, respectively, while the mean annual temperature is $12.6^{\circ} \mathrm{C}$.

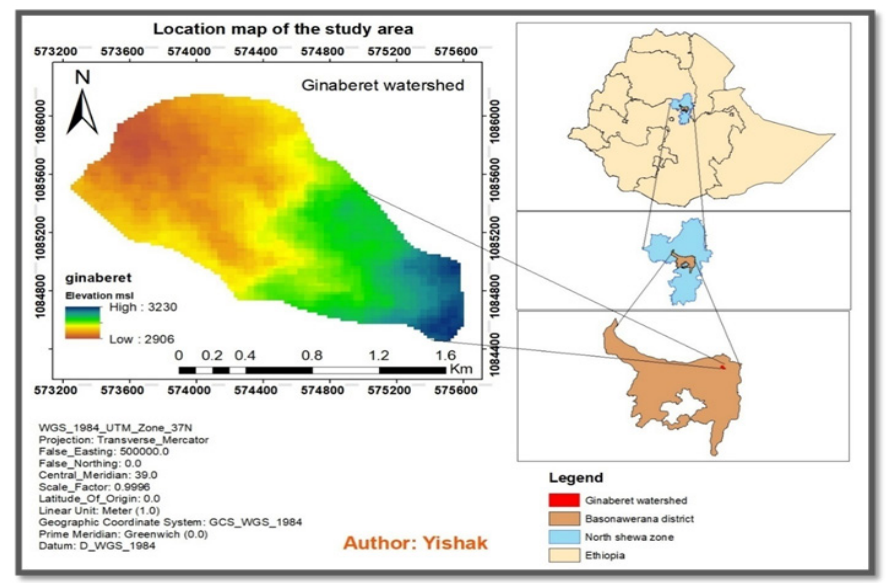

Figure I Map of the study area.

The mixed crop-livestock system is the predominant farming system in the study. The feed sources are, crop residues, grazing land and cultivated feeds (Tree lucerne and phalaris). The study area has two rainy seasons; kiremt (long season) and belg (short season) which occurs between June and September and between February and April, respectively. During kiremt season, wheat, faba bean, barley and field pea are grown and barley is the major crop during belg season. The dominant soil types in the study area are Eutric cambisols (42\%) and Eutric Leptosols (58\%). The three conserved land (A, B, and C) were selected through reconnaissance survey. Site A was conserved for 5years; soil and stone bund and with tree lucerne and phalaris grass were constructed (Figure 2, Plate $1 \&$ plate 2). Site B was also conserved for 5years; soil and stone bund and with phalaris grass 
and terrace were constructed. Site C was conserved for 7years; soil and stone bund and with tree lucerne and phalaris grass and terrace were constructed. The three non-conserved lands (X, Y, and Z) were selected through reconnaissance survey.

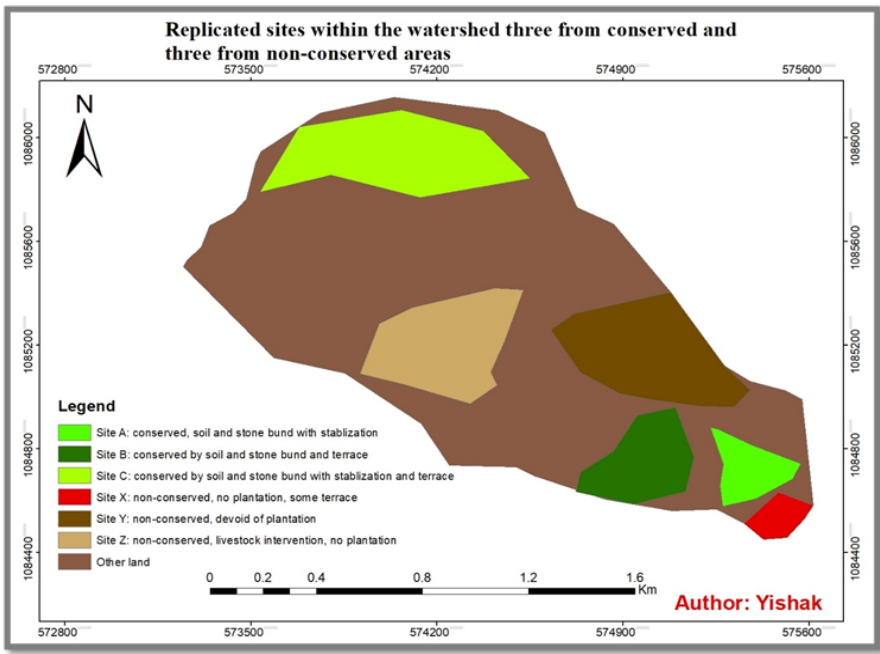

Figure 2 Treatment and replication map within the watershed.

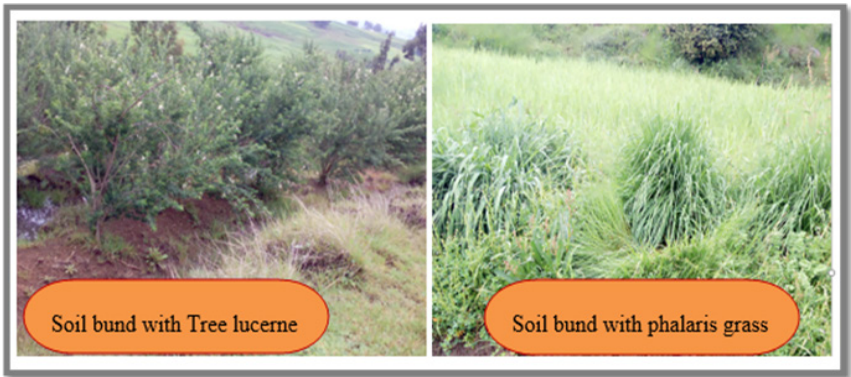

Plate I Conserved areas within the watershed (Photo by Yishak)

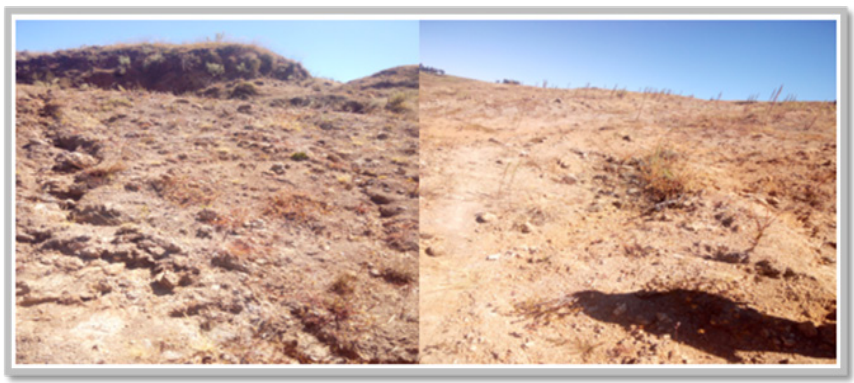

Plate 2 Non-conserved areas within the watershed (Photo by Yishak).

\section{Revised universal soil loss equation (RUSLE)}

Estimation of soil erosion has been anticipated by means of Revised Universal Soil Loss Equation (RUSLE). It is a method to estimate the possible soil loss from splash, sheet, and rill erosions..$^{10}$ The factors used in RUSLE were obtained from the meteorological station, field survey, soil surveys and soil data, DEM and satellite image. The input factors for the RUSLE model in this study were adapted to Ethiopian conditions by Hurni ${ }^{11}$. RUSLE model is more efficient for a small area because it does not have the capability for routing sediment through channels. ${ }^{12}$ The flow chart is indicated in Figure 3.

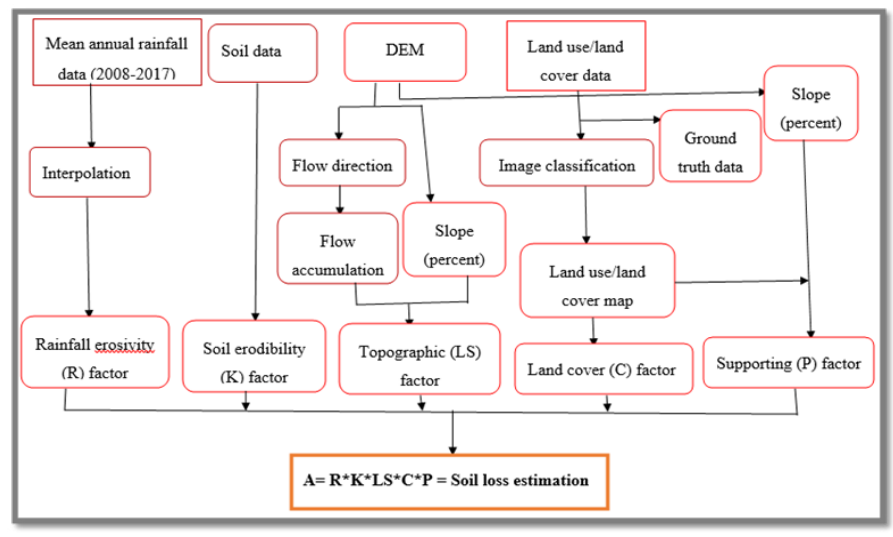

Figure 3 Flowchart showing RUSLE parameters for soil loss prediction.

Mathematically, the RUSLE equation is represented as:

$$
A=\mathrm{R} * \mathrm{~K}^{*} \mathrm{~L} \mathrm{~S} * \mathrm{C} * \mathrm{P}
$$

Where: $\mathbf{A}$ is average annual soil loss (tons/ha/yr), $\mathbf{R}$ is rainfall erosivity factor (MJ.mm/h/ha/yr), $\mathbf{K}$ is soil erodibility factor (tons/ $\mathrm{ha} / \mathrm{MJ} / \mathrm{mm}$ ), $\mathbf{L S}$ is a topographic factor (dimensionless), $\mathbf{C}$ is crop cover factor (dimensionless), and $\mathbf{P}$ is soil conservation practice factor (dimensionless).

\section{Rainfall erosivity factor ( $R$-factor)}

The $\mathrm{R}$-factor represents the erosive force of a specific rainfall event. ${ }^{13}$ Hurni ${ }^{11}$ point out the spatial regression analyses derived an equation from available mean annual rainfall $(\mathrm{P})$ as an alternative to Ethiopian condition. For this study, mean annual rainfall data from the year, 2008 to 2017 were collected from two representative meteorological stations, i.e., Debre Berhan Agricultural Research Center (DARC) and Andit Tid soil conservation research station. The recorded data were first interpolated to generate continuous rainfall data for each grid cell by "Raster Kriging Interpolation" method in the ArcGIS environment thereby calculates the mean rainfall erosivity factor ( $\mathrm{R}$-value). R-factor was computed for each meteorological station using the following equation: ${ }^{11}$

$$
\mathrm{R}=-8.12+\left(0.562^{*} \mathrm{P}\right)
$$

Where; $\mathrm{P}$ is the mean annual rainfall in $\mathrm{mm}$; $\mathrm{R}$ is erosivity factor. To produce the $\mathrm{R}$-factor map, the interpolated $\mathrm{R}$-factors were converted into a raster format with $20 \mathrm{~m}$ resolution and extracted for the studied watershed area.

\section{Soil erodibility (K-factor)}

Soil erodibility is strongly related to the physical properties of the soil and plays an important role in soil conservation strategies. ${ }^{14}$ In this study, soil type is found from soil unit map of the study area from Amhara Region digital soil map developed at a scale of 1: $50,000 .{ }^{15}$ The soil erodibility factor within the watershed was estimated adapted from Hurni ${ }^{11}$ (Table 1). The shapefile of the soil unit map of the watershed was changed to a raster with a cell size of $20 \mathrm{~m}$ x $20 \mathrm{~m}$ and reclassified based on $\mathrm{K}$-values.

\section{Slope and slope length factor (LS-factor)}

Slope and slope length (LS-factor) was determined from both the slope length and slope gradient. Digital elevation model (DEM) with 
$20 \mathrm{~m}$ spatial resolution and GIS technique were used to generate slope gradient and slope length as referred from Nekhay et al. ${ }^{16}$ Spatial Analyst Tool Map Algebra Raster Calculator in Arc GIS 10.3.1 environment was used to multiple slope maps and flow accumulation and next calculate and generate the topographic factor map. The flow accumulation was calculated from the Spatial Analyst Hydrology toolset of ArcMap in ArcGIS environment. The slope of the study area in percentage was calculated by the Slope tool in the Spatial Analyst Surface toolset of ArcMap from digital elevation model (DEM) of the watershed.

Table I Estimated K-value for some Ethiopian soils

\begin{tabular}{ll}
\hline Soil type & Estimated K-value \\
\hline Andosols, Vertisols, and Leptosols & 0.15 \\
Cambisols, Phaeozems, Regosols, and Luvisols & 0.20 \\
Lixisols, Nitosols, and Alisols & 0.25 \\
Fluvisols, and Xerosols & 0.30 \\
\hline
\end{tabular}

Source Hurnil"

The equation for topographic factors (LS) by Wischmeier \& Smith

$$
\mathrm{LS}=\left(\frac{\mathrm{X}}{22.1}\right)^{t}\left(0.065+0.045 \mathrm{~S}+0.0065 \mathrm{~S}^{2}\right.
$$

Where $\mathrm{X}=$ slope length ( $\mathrm{m}$ ) and $\mathrm{S}=$ slope gradient (\%)

$$
\mathrm{X}=(\text { Flow accumulation } * \text { Cell value })
$$

Flow accumulation is the total number of cells, including nonneighboring cells that drain into a selected cell in the raster-based analysis. Then we substituted the $\mathrm{X}$ value on LS

$$
\mathrm{LS}=\left(\text { Flow accumulation } * \frac{\text { Cell value }}{22.1}\right)^{t}\left(0.065+0.045 \mathrm{~S}+0.0065 \mathrm{~S}^{2}\right)
$$

Cell size is $20 \mathrm{~m}$ and the value of " $\mathrm{t}$ "varies from $0.3-0.5$ depending on the slope value ( $\mathrm{t}=0.5$ if $\mathrm{S} \geq 5 \%$; $\mathrm{t}=0.4$ if $3 \% \leq \mathrm{S}<5 \%$; $\mathrm{t}=0.3$ if $1 \% \leq \mathrm{S}<3 \%, \mathrm{t}=0.2$ if $\mathrm{S}<1 \% .{ }^{17}$

\section{Land covers (C-factor)}

Landsat satellite image was imported into ERDAS 2014 software in an image format for supervised digital image classification for land use and land cover mapping. Ground truth data were used as a reference for accuracy assessment which determines the information value of the resulting data to the user. ${ }^{18}$ This was obtained through ground verification using Global Position System; next, compares of the classified image to an image which is assumed to be corrected by Google Earth Image, and finaly, interviewing for concerned bodies these have previous information. The corresponding $\mathrm{C}$-value was assigned to each land use class for Ginaberet watershed using the re-class method in Arc GIS as established C-values for Ethiopian condition by Hurni ${ }^{11}$ presented in Table 2 .

\section{Conservation practice factor (P-factor)}

Factor $\mathrm{P}$ in the RUSLE is the proportion of soil loss with a specific support practice to the matching loss by up and downslope principles (Table 3). The P-factor for RUSLE was mapped using data from frequent field observations as explained by Tadesse \& Abebe, ${ }^{19}$ According to Atesmachew et al. ${ }^{20}$ management activities are highly dependent on the slope of the area under consideration. The $\mathrm{P}$-factor for this study was determined using slope and land cover data as suggested by Wischmeier $\&$ Smith $^{21}$. This method categorizes the land cover into agricultural land and other land covers. The established $\mathrm{P}-$ value was changed into raster map with a cell size of $20 \mathrm{~m}$.

Table 2 C-factor value for different land use management

\begin{tabular}{ll}
\hline Land use & C-factor values \\
\hline Grazing Land & 0.12 \\
Crop Land & 0.37 \\
Built Up Areas & 0.01 \\
Rocky Area & 0.05 \\
Forest Land & 0.05 \\
Water Body & 0.00
\end{tabular}

Source Hurni"l

Table 3 Management practice factor, P-value

\begin{tabular}{lll}
\hline Land use type & Slope (\%) & P-value \\
\hline & $>50$ & 0.33 \\
& $30-50$ & 0.25 \\
Cultivated Land & $15-30$ & 0.19 \\
& $8-15$ & 0.14 \\
& $3-8$ & 0.12 \\
Built-up Area & All & 0.10 \\
Forest Land & All & 1.00 \\
Grazing Land & All & 1.00 \\
Rocky Area & All & 0.90 \\
Terraces & All & 0.80
\end{tabular}

Source Wischmeier \& Smith ${ }^{21}$

\section{Soil sampling}

Undisturbed soil samples were collected using a core sampler for the determination of bulk density. The two treatments are a conserved area with SWC practice of both mechanical and biological measures and non-conserved (without SWC practice) with three replications for each. Simple random sampling with zigzag manner was used. Besides, soil depth in each specific study site was estimated at three representative points and the average estimated value was used to estimate the permissible soil loss amount.

\section{Soil loss prediction using RUSLE model analysis}

The rate of soil loss of soil due to soil erosion was estimated by means of revised universal soil loss equation (RUSLE). The maximum erosion rates recognized in each of the study areas were computed by multiplying maps of the erosion factors in RUSLE presented in equation-1 above. The rate of soil loss was estimated factor tables adapted by Hurni ${ }^{11}$ for the Ethiopian conditions.

\section{Laboratory analysis}

The composite soil samples were collected and dried, mixed well, and passed through a $2 \mathrm{~mm}$ sieve for soil texture analysis at Debre Berhan Agricultural Research Center soil laboratory. Soil texture was estimated by using the hydrometer method. ${ }^{22}$ Besides undisturbed core samples were collected for soil bulk density, total porosity, and soil moisture content determination. Soil bulk density was determined as the ratio of oven dry soil mass to its volume after drying the soil samples in an oven at $105^{\circ} \mathrm{C}$ for about 24 hours..$^{23}$ 


$$
\mathrm{b}=\frac{\mathrm{Ms}}{\mathrm{Vb}}
$$

Where: $\rho b=$ soil bulk density $\left(\mathrm{g} / \mathrm{cm}^{3}\right), \mathrm{Ms}=$ dry soil mass $(\mathrm{g}), \mathrm{Vb}=$ volume of the soil sample $\left(\mathrm{cm}^{3}\right)$

The particle density of most soils varies from 2.60 to $2.75 \mathrm{~g} / \mathrm{cm}^{3} .^{24}$ A value of $2.65 \mathrm{~g} / \mathrm{cm}^{3}$ is generally assumed as averaged for particle density, therefore, this value was used for this study. Total porosity was calculated using equation-8.

$$
\text { Pore } \operatorname{space}(\%)=\frac{\mathrm{d}-\mathrm{b}}{\mathrm{d}} * 100 \%
$$

Where: $\rho d=$ Particle density $\left(\mathrm{g} / \mathrm{cm}^{3}\right) ;{ }^{\rho b}=$ Bulk density $\left(\mathrm{g} / \mathrm{cm}^{3}\right)$ Soil moisture content was determined by the gravimetric method and is analyzed based on the oven dry basis. ${ }^{25}$

$$
\text { Soil moisture content }(\%)=\frac{\text { wet soil }- \text { dry soil }}{\text { dry soil }} * 100
$$

Soil structure was described in terms of shape or type in which crumb, granular, angular blocky, subangular blocky; size (fine, medium, coarse), and grade (distinctness) of the aggregates (weak, moderate, strong). Comparing and contrasting between soil structure conditions between conserved and non-conserved study areas were also done.

\section{Result and discussion}

\section{Soil loss estimation using RUSLE model}

\section{Rainfall erosivity factor $(\mathbf{R})$}

The long-term mean annual rainfall did not show differences among the specific study sites that is $1498 \mathrm{~mm}$ similar to the watershed rainfall. Consequently, the $\mathrm{R}$-factor resulted value was 833 and the spatial distribution of $\mathrm{R}$ assumed to be uniform throughout the watershed area (Figure 4). This is accounted for the smaller size of the watershed. ${ }^{26}$

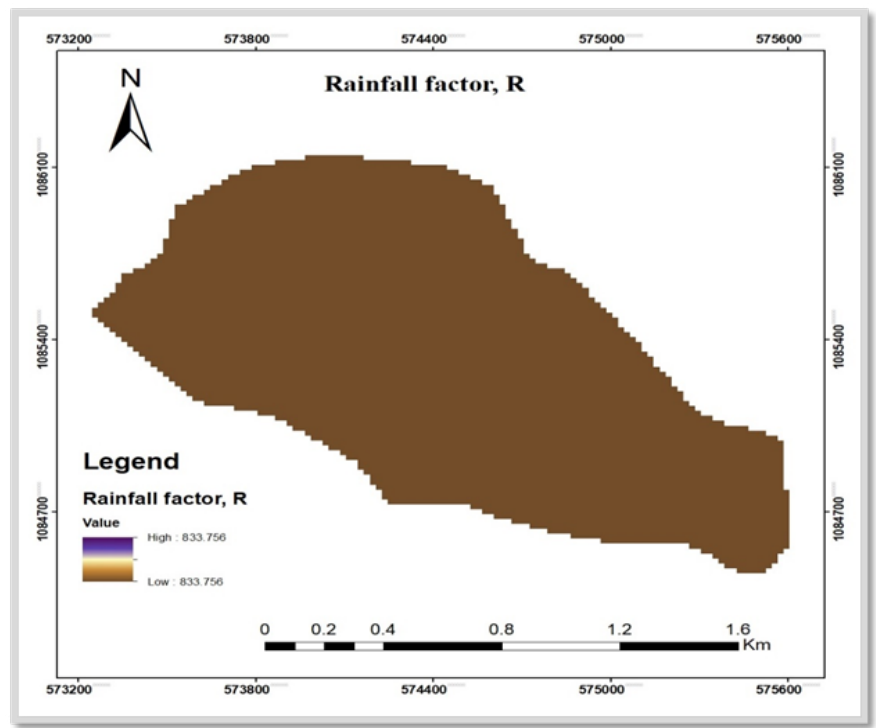

Figure 4 Map of rainfall erosivity factor (R).

\section{Soil erodibility factor $(\mathbf{K})$}

Two major soil type categories were identified in the study area. After assigning $\mathrm{K}$-values for both soil types, the soil map was reclassified using adopted $\mathrm{K}$-values by Hurni ${ }^{11}$ with a grid map of $20 \mathrm{~m} \times 20 \mathrm{~m}$ cell size. The value of $\mathrm{K}$-factor was found to be between 0.15 and 0.2 for the study area. Eutric Cambisols and Eutric Leptosols are the major soil types in the watershed with the covering of $42 \%$ and $58 \%$ of the land to the corresponding $\mathrm{K}$-value of 0.2 and 0.15 (Figure 5 ). The overall erodibility range of the watershed was very low. ${ }^{27}$

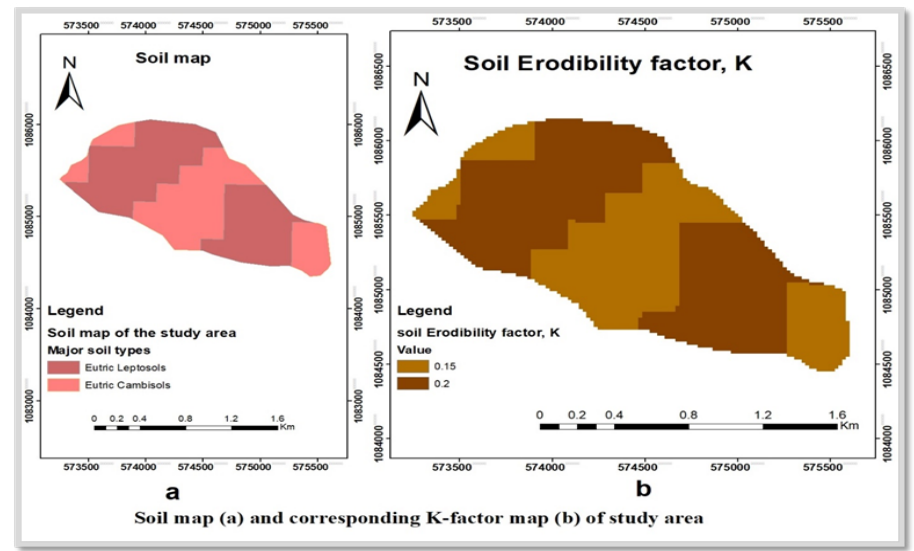

Figure 5 Soil and soil erodibility factor (K) map.

\section{Topographic factor (LS)}

Topographic factor map was generated using the formula in ArcGIS spatial analysis raster calculator function. Figure 6 showed that the slope steepness and the slope length factors in the watershed varied from 0 up to 41.19 to soil erosion. However, the mean LS value of the study watershed was 1.44 . The majority slope value was concentrated near to zero implies that topographic factor has less effect on soil erosion in the study area.

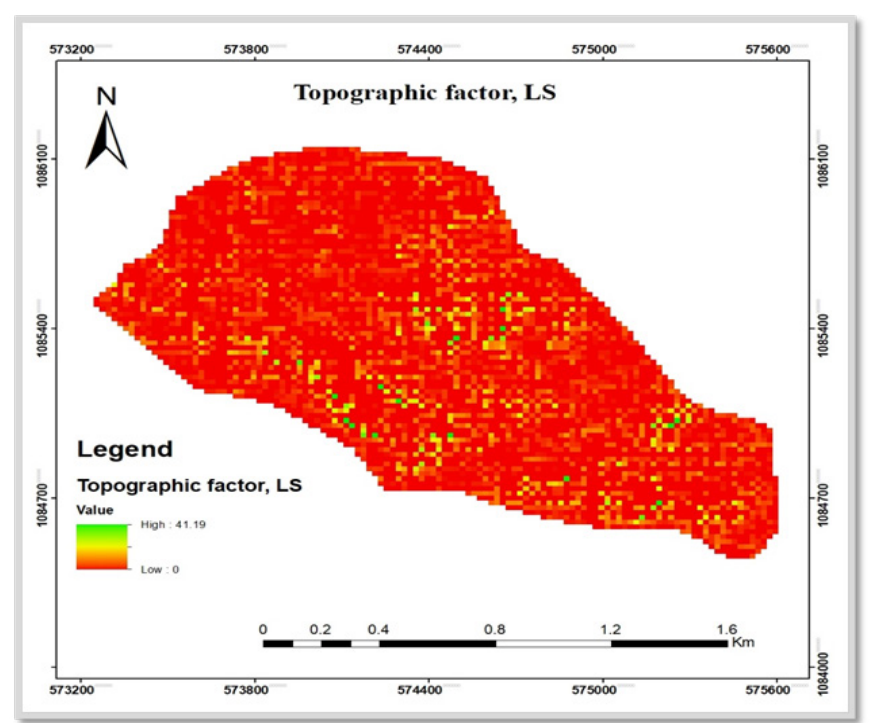

Figure 6 Map of topographic factor (LS).

\section{Land cover factor $(C)$}

Cover and management factor (C) for Ginaberet watershed was ranging between 0.01 and 0.37 as indicated in Figure 7. Six land use classes were recognized in the watershed dominated by cropland 
(176.6ha) followed by grazing land (32.7ha), forestland (5.4ha), rocky area (1.5ha), built up area (0.25ha), and water body (0.031ha). The corresponding land cover factor values were found to be $0.37,0.12$, $0.05,0.05,0.01$, and 0.00 respectively. The higher $\mathrm{C}-$ value $(0.37)$ is an indication that the larger land use $(81.7 \%)$, i.e., the cropland, contributes more to soil erosion in the watershed (Figure 7). It was similar to the work of Morgan ${ }^{28}$ and Gizachew. ${ }^{29}$

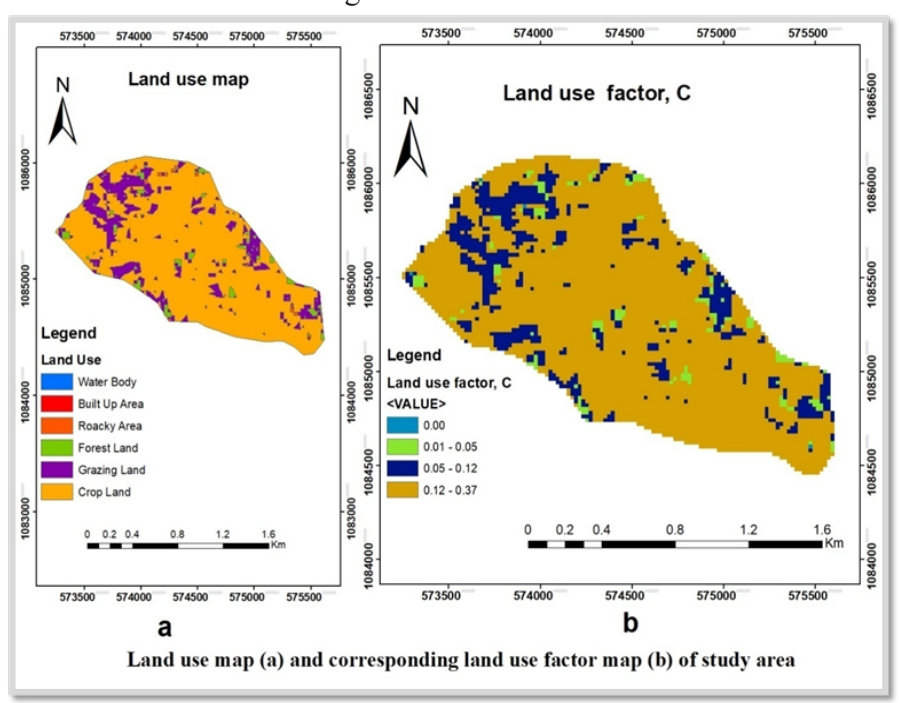

Figure 7 Land use and land cover factor (C) map.

\section{Supporting factor $(\mathrm{P})$}

The value of $\mathrm{P}$ factor depends upon the measures of soil management, which is associated with the slope of the area. In the study area, most part of the area has been treated with different soil and water conservation practices including soil and stone bund and soil and stone bund with tree lucerne and phalaris, and terrace but not a long period of time (less than fiveyears). The management factor value of each land cover class was determined in the watershed based on the adapted values ${ }^{11}$ for Ethiopian condition. After Hurni, the cultivated lands are classified into six slope categories and assigned the corresponding $\mathrm{P}$ values. ${ }^{30}$ The result revealed that from the 127.9 ha cultivated land 106.74 ha $(59.2 \%)$ have a slope range of $0-30 \%$ with $\mathrm{P}$ value ranging between 0.1 and 0.19 (Figure 8). In terms of P value, another land use (built-up area, forestland, grazing land, rocky area, and terraces) was more contributor to the soil erosion with the area coverage of 87.93 ha $(40.7 \%)$ within the watershed. It implies $\mathrm{P}-$ factor was the most contributors to soil erosion next to rainfall (R) factor Table 4.

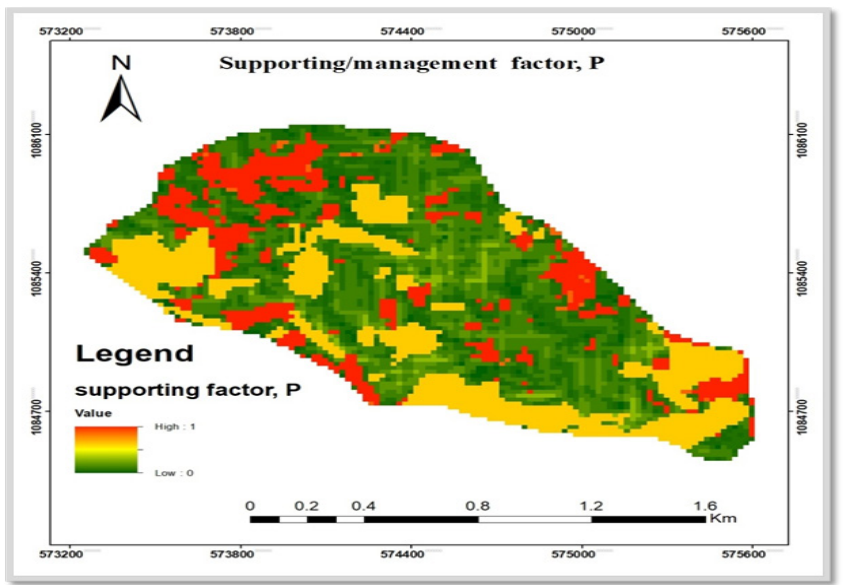

Figure 8 Map of management factor $(\mathrm{P})$.
Based on the principles of RUSLE model, the spatial soil erosion rate was computed through the cell by cell multiplication of the six thematic parameters in Raster calculator of ArcGIS spatial analysis function. The result revealed that the mean and the total annual soil loss rate of the study watershed were found to be 25 tons/ha/yr and the annual volume of soil loss 1394.44 tons Table 5. This is comparable to the average soil loss rate reported by Hurni ${ }^{11}$ for the highlands (18tons/ $\mathrm{ha} / \mathrm{yr}$ ). The current result also agrees with similar findings in Ethiopia as reported by Tadesse \& Abebe $^{19}$ for the Jabi Tehinan watershed in the northwestern highlands (30.4tons/ha/yr) and in Amare et al. ${ }^{31}$ for the Wondo Genet watershed of the eastern highlands (26tons/ha/yr). In Koga watershed of the Blue Nile basin the average soil erosion rate was 47 . tons $/ \mathrm{ha} / \mathrm{y} .{ }^{32}$

Table 4 Soil loss rating and area coverage of Gina beret watershed

\begin{tabular}{lllll}
\hline Class & tons/ha/yr & Descriptions & Ha & $\%$ \\
\hline I & $0-5$ & None to slight & 147.02 & 68.1 \\
II & I5-May & Slight & 17.45 & 8.2 \\
III & $15-30$ & Slight to moderate & 13.68 & 6.3 \\
IV & $30-50$ & Moderate & 12.9 & 5.9 \\
V & $50-100$ & High & 11.58 & 5.4 \\
VI & $100-200$ & Very High & 8.74 & 4 \\
VII & $>200$ & Very High & $4.4 I$ & 2 \\
& & Total & 215.85 & 100 \\
\hline
\end{tabular}

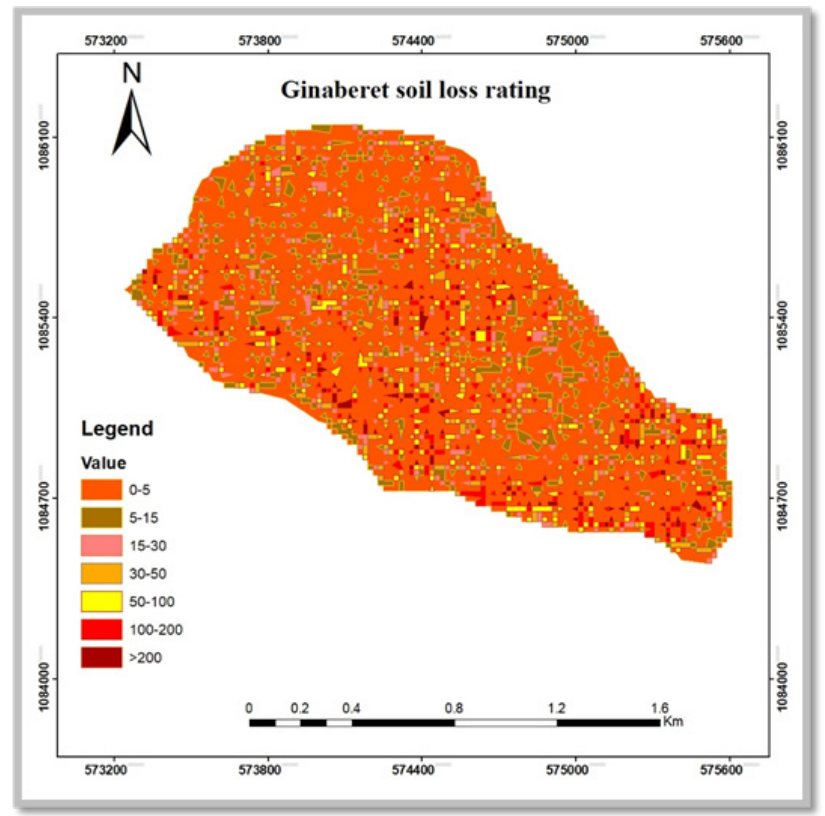

Figure 9 The final result of spatial soil loss rate.

From the five factors used for analyzing soil erosion using RUSLE model, rainfall factor (R) was the most dominant factor to contribute soil erosion (Figure 4); the result implies that conservation management factor $(\mathrm{P})$ was the dominant factor next to rainfall factor (Figure 8) and the next was $\mathrm{C}$ factor (Figure 7). Topographic factor (LS) (Figure 9) and soil erodibility factor (K) (Figure 5) were less contributors to soil erosion respectively. The soil loss rate with respect to the area coverage is presented in Table 6 . With soil loss rate range of $0-5$ tons $/ \mathrm{ha} / \mathrm{yr}$ (none to slight) was covered the large area of the watershed of 147.02 ha $(68.1 \%)$ and the next $5-15$ tons/ha/yr (slight) was covered 17.45 ha $(8.2 \%)$ of the watershed. Similar result was reported by Gizachew ${ }^{29}$ in Zingin watershed. 


\section{Soil loss rating on conserved and non-conserved fields from RUSLE}

The soil loss rate in the specific study areas are presented in Figure 4. In conserved areas, the average soil loss rates are found to be 52, 15.59 and 8.56 tons/ha/yr respectively in area A, B, and C. Similarly, the average soil loss rates in the specific non-conserved areas are found to be 19,30 and 43.6 tons/ha/yr respectively in area $\mathrm{X}, \mathrm{Y}$, and Z. The overall mean soil loss rating was 25.59 tons/ha/yr and 30.92 tons/ha/yr, respectively for conserved and non-conserved areas. That implies a relatively greater amount of soil particle was removed in case of erosion from non-conserved land rather than conserved areas (Table 4) (Figure 10).

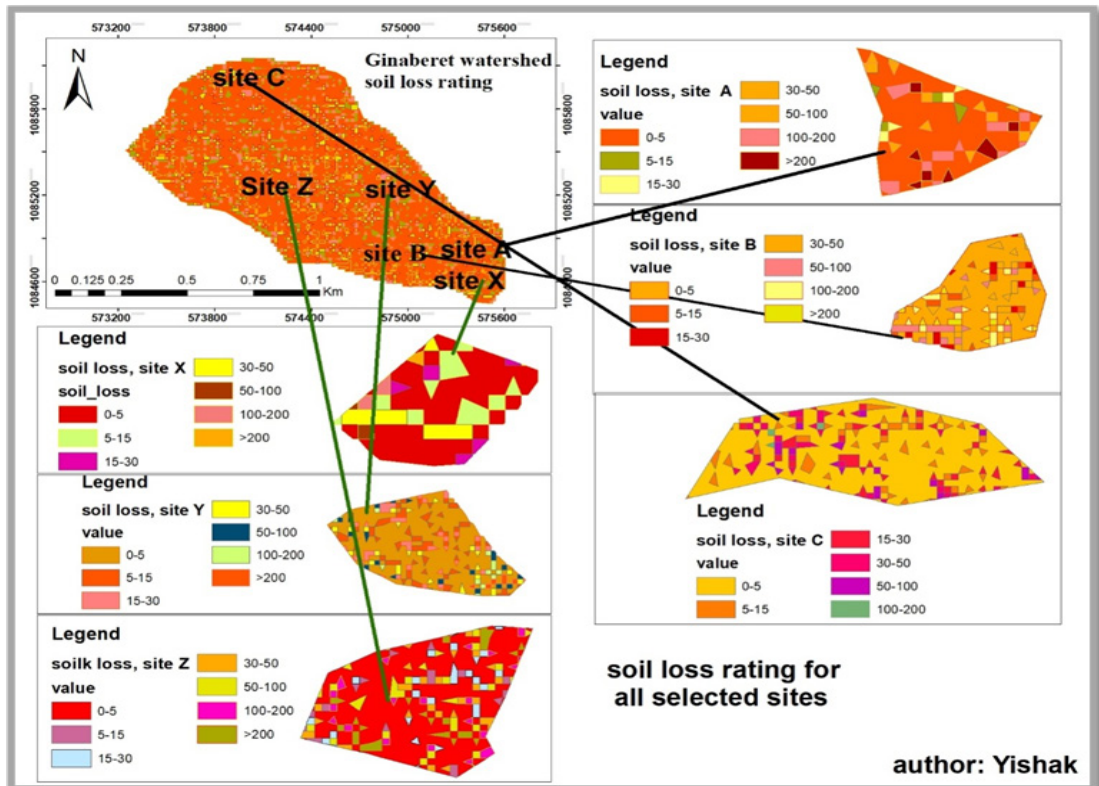

Figure 10 Spatial soil loss rate in conserved and non-conserved areas.

Table 5 Soil loss rating and area coverage for each specific conserved and non-conserved area

\begin{tabular}{|c|c|c|c|c|c|c|c|c|}
\hline \multicolumn{3}{|c|}{ Soil loss rating } & \multicolumn{2}{|c|}{ Site A } & \multicolumn{2}{|c|}{ Site B } & \multicolumn{2}{|c|}{ Site C } \\
\hline Class & tons/ha/yr & Descriptions & $\mathrm{Ha}$ & $\%$ & $\mathrm{Ha}$ & $\%$ & $\mathbf{H a}$ & $\%$ \\
\hline I & $0-5$ & None to slight & 3.99 & 73.2 & 7.13 & 69 & 16.51 & 76.5 \\
\hline II & I5-May & Slight & 0.15 & 2.8 & 0.42 & 4.1 & 1.79 & 8.3 \\
\hline III & $15-30$ & Slight to moderate & 0.11 & 2 & 0.43 & 4.2 & 1.39 & 6.4 \\
\hline IV & $30-50$ & Moderate & 0.07 & 1.3 & 0.78 & 7.6 & 1.07 & 4.9 \\
\hline$\vee$ & $50-100$ & High & 0.31 & 5.7 & 0.69 & 6.7 & 0.71 & 3.3 \\
\hline VI & $100-200$ & Very High & $0.5 \mathrm{I}$ & 9.4 & 0.57 & 5.5 & 0.11 & 0.5 \\
\hline \multirow[t]{2}{*}{ VII } & $>200$ & Very high & 0.29 & 5.3 & 0.32 & 3.1 & - & - \\
\hline & & Total & 5.45 & 100 & 10.33 & 100 & 21.58 & 100 \\
\hline \multicolumn{2}{|c|}{ Soil loss rating } & & \multicolumn{2}{|c|}{ Site $X$} & \multicolumn{2}{|c|}{ Site $Y$} & \multicolumn{2}{|c|}{ Site $\mathbf{Z}$} \\
\hline Class & tons/ha/yr & Descriptions & $\mathrm{Ha}$ & $\%$ & $\mathbf{H a}$ & $\%$ & $\mathrm{Ha}$ & $\%$ \\
\hline I & $0-5$ & None to slight & 1.69 & 63.3 & $|3.6|$ & 68.6 & 12.23 & 70.7 \\
\hline II & I5-May & Slight & 0.41 & 15.4 & 2.61 & 13.2 & 0.52 & 3 \\
\hline III & $15-30$ & Slight to moderate & 0.12 & 4.5 & 1.47 & 7.4 & 0.86 & 4.9 \\
\hline IV & $30-50$ & Moderate & 0.29 & 10.9 & 0.86 & 4.3 & 0.94 & 5.4 \\
\hline V & $50-100$ & High & 0.05 & 1.9 & 0.69 & 3.5 & 1.04 & 6 \\
\hline VI & $100-200$ & Very High & 0.07 & 2.6 & 0.42 & 2.1 & 0.74 & 4.2 \\
\hline \multirow[t]{2}{*}{ VII } & $>200$ & Very high & 0.03 & 1.1 & 0.23 & 1.2 & 0.99 & 5.8 \\
\hline & & Total & 2.67 & 100 & 19.83 & 100 & 17.32 & 100 \\
\hline
\end{tabular}


Table 6 Comparing soil loss with soil loss tolerance limit

\begin{tabular}{|c|c|c|c|c|}
\hline \multirow{2}{*}{ Treatment } & \multirow{2}{*}{ Replication } & Estimated soil loss & \multirow{2}{*}{ Soil depth(cm) } & \multirow{2}{*}{ Remark on tolerance limit } \\
\hline & & RUSLE (ton/ha/yr) & & \\
\hline \multirow{4}{*}{ Conserved } & A & 52 & $50-100$ & not permissible \\
\hline & B & 15.59 & $25-50$ & not permissible \\
\hline & $\mathrm{C}$ & 8.56 & $50-100$ & Permissible (RUSLE) \\
\hline & Average & 25.4 & $50-100$ & not permissible \\
\hline \multirow{4}{*}{ Non- conserved } & $x$ & 19 & $50-100$ & not permissible \\
\hline & $Y$ & 30 & $25-50$ & not permissible \\
\hline & Z & 43.6 & $25-50$ & not permissible \\
\hline & Average & 30.86 & $25-50$ & not permissible \\
\hline
\end{tabular}

Table 7 Area coverage of permissible soil loss for each soil depth classes of the study area

\begin{tabular}{|c|c|c|c|c|c|c|}
\hline \multirow{2}{*}{$\begin{array}{l}\text { Permissible } \\
\text { soil loss (ton/ha/yr) }\end{array}$} & \multicolumn{5}{|c|}{ Soil depth (cm) } & \multirow{2}{*}{ Area(ha) } \\
\hline & $0-25$ & $25-50$ & $50-100$ & $100-150$ & $>150$ & \\
\hline $0-2$ & 97.52 & & & & & 97.52 \\
\hline $2-5$ & & 22.15 & & & & 22.15 \\
\hline $5-7$ & & & 14.78 & & & 14.78 \\
\hline $7-9$ & & & & 13.88 & & 13.88 \\
\hline $9-11$ & & & & & 10.55 & 10.55 \\
\hline Area under the tolerable soil loss & 97.52 & 22.15 & 14.78 & 13.88 & 10.55 & 158.88 \\
\hline
\end{tabular}

The soil loss rate of conserved and non-conserved areas with respect to the area coverage is presented in Table 7. In suite A, B, and $\mathrm{C}$, soil loss rate range of $0-5$ tons $/ \mathrm{ha} / \mathrm{yr}$ (none to slight) was covered the large area of $73.2 \%, 69.0 \%$, and $76.5 \%$ in conserved areas (Table 7). The next 100-200tons/ha/yr (very high) was covered $9.4 \%$ in site A; 30-50tons/ha/yr (moderate) covered $7.6 \%$ in site B and 5-15tons/ ha/yr (slight) covered $8.3 \%$ in site $\mathrm{C}$ in conserved areas. In site $\mathrm{X}$, $\mathrm{Y}$, and $\mathrm{Z}$, soil loss rate range of $0-5$ tons $/ \mathrm{ha} / \mathrm{yr}$ (none to slight) was covered the large area of $63.3 \%, 68.6 \%$, and $70.7 \%$ in non-conserved areas. The next 5-15tons/ha/yr (slight) was covered $15.4 \%$ in site X; $5-15$ tons/ha/yr (slight) was covered $13.2 \%$ in site $\mathrm{Y}$ and $50-100$ tons/ $\mathrm{ha} / \mathrm{yr}$ (high) covered $6.0 \%$ in site $\mathrm{Z}$ in non-conserved areas within the watershed (Table 5).

These values were higher than the mean value from RUSLE, which were 25.59 tons/ha/yr and 30.92 tons/ha/yr in conserved and non-conserved areas. When the result compared to results from other areas, it is not the least or the highest in both conserved and non-conserved. Several results were reported as 23.7 tons/ha/yr, 32 . Temesgen ${ }^{33}$ in Geleda watershed, Blue Nile basin, Ethiopia; 9.10tons/ ha/yr at Zingin watershed in Awi Zone. ${ }^{29}$ The estimated average soil loss from croplands in the Ethiopian highlands as a whole was 100 tons/ha/yr by Mati et al. ${ }^{34}$ The average of 20 tons/ha/yr was estimated by Hurni ${ }^{11}$ in the highland of Ethiopia and measured amounts of more than 300 tons/ha/yr on specific plots. Hurni ${ }^{3}$ estimated mean soil loss from cultivated fields as 42 tons/ha/yr. A study by Kebede et al. ${ }^{35}$ in the central rift valley watershed reported a relatively high rate of soil erosion as 45 tons/ha/yr. The average annual soil loss from the test plots in Anjani watershed without conservation measures was reported to 110 tons/ha/yr. ${ }^{36}$ Thus, our estimated soil loss rate was generally realistic on both conserved and non-conserved areas, compared to results from previous studies but greater on non-conserved when compared from conserved areas in this study within the watershed.

\section{Comparing soil loss rate with soil loss tolerance limit}

Result from RUSLE model, site C was under permissible (8.56ton/ $\mathrm{ha} / \mathrm{yr}$ ) but sites A and B it was greater than the permissible limit and the mean of the three sites also greater than the permissible limit (Table 6). Based on the level of soil loss tolerance limits in Table 1 referenced from soil depth, 158.88 ha falls below the tolerable soil loss limit and the remaining 56.97 ha was found to be higher than the tolerable soil loss limit. Soil loss rate of $9-11$ tons/ha/yr with the corresponding area coverage of 10.50 ha in the deeper soil range was the maximum tolerable soil loss tolerance. The majority of the watershed area has soil loss tolerance $0-2$ tons $/ \mathrm{ha} / \mathrm{yr}$ with corresponding area coverage of 97.52ha (Table 7).

\section{Soil physical properties affected by soil erosion and soil conservation}

Higher OM resulted from conservation measures and decay of plant residues in the treatments. Similar results were reported by Haweni ${ }^{37}$ and Solomon et al. ${ }^{30}$ Contrasting results were also reported. ${ }^{38-40}$ The soil physical properties in the study areas were not affected by SWC practices as compared to the non-conserved areas. These are attributed to the young age of SWC measures (since 5years). The result depicts that significant changes or effects of SWC on soil characteristics can be achieved only over a long period of conservation practices. ${ }^{37}$

This soil texture did change as a result of soil erosion and conservation within a short period of time. However, there was a slight numerical variation of sand, silt, and clay fraction between areas with and without conservation. Jamala \& $\mathrm{Oke}^{41}$ reported that soil texture is an intrinsic soil property, but intensive cultivation could contribute to the variations in particle size distribution at the surface horizon of cultivated and natural fallow land. The sand fraction was relatively high value in the non-conserved area $(27.67 \%)$ than the conserved 
$(12 \%)$ numerically. The silt content was higher in the conserved areas $(50.67 \%)$ than in the non-conserved areas $(36 \%)$. Similarly, higher mean silt proportion in woodland and fallow land than in cultivated land without soil bunds was reported. ${ }^{9}$ However, the result of the silt content was not in concurrence with Daniel et al. ${ }^{42}$ who reported higher silt content in non-conserved areas than conserved lands.

The proportion of clay content in both the conserved and nonconserved areas was below 50\% with slightly increment $(1 \%)$ in conserved than non-conserved. The result implies that this may be due to the direct result of the chemical weathering of silicate minerals from the prevalence sedimentary rocks in the study area. The numerically greater value of mean soil moisture content was observed in conserved areas rather than non-conserved areas although do not show the statistically significant difference. This may be due to the level of conservation and level of soil erosion and lack of full vegetation cover of the land throughout the year. ${ }^{38}$

The numerically highest mean bulk density (BD) was recorded in the non-conserved field rather than the conserved field. The numerical variation of soil bulk density is expected due to the absence of soil conservation leading to the removal of soil organic matter and weakness in the natural stability of soil aggregates making it susceptible to erosion..$^{38}$ According to Landon the soil with a mean of $1.5 \mathrm{~g} / \mathrm{cm}^{3}$ in the non-conserved land of bulk density ranges with soils showing root restriction which reduces the plant's ability to exploit the plant environment. In this study, $1.55 \mathrm{~g} / \mathrm{cm}^{3}$ resulted in non-conserved areas which imply the presence of root restriction in the non-conserved study areas.

Slightly higher mean value of soil porosity was recorded in the conserved areas $(47.67 \%)$ rather than non-conserved $(42.8 \%)$, but also no statistically significant difference at $(p<0.05)$ levels. This in-significance level of difference is attributed to the selected extent of land degradation and level of conservation and selection of planting tree which is best to contribute to the soil organic matter thereby improve soil porosity. The soil physical properties can be altered by the management practices through a longer period of time rather than over a short period. Moreover, accumulation of plant litter produced by the various trees and grasses allows greater infiltration of rainwater thereby preventing the quick loss of soil moisture and increasing the soil water holding capacity in a long period of time. ${ }^{43}$ Longer time is needed to fully understand the impact of soil conservation on soil physical properties. ${ }^{44}$ Based on the field observation and the remote sensing data analysis results, noticeable vegetation cover improvement has been observed in the 30years' period. ${ }^{30}$ Similarly, Jay et al. $^{45}$ showed that tillage effect after 22 years of treatment imposition not effectively altered soil $\mathrm{BD}$ and soil moisture content. In contrast, soil physical properties were affected significantly by soil conservation. ${ }^{9,46}$ These were related to the young age of the constructed SWC measures, implying that significant changes or effects of SWC on soil characteristics can be achieved only over a long period of conservation. ${ }^{37}$

Table 8 The mean difference of soil physical properties between conserved and non-conserved areas

\begin{tabular}{llllllll}
\hline Treatments & BD(g/cc) & PPs(\%) & SMC(\%) & Sand(\%) & Silt(\%) & Clay(\%) & Textural class \\
\hline Conserved & $1.37 \mathrm{a}$ & $47.67 \mathrm{a}$ & $20.4 \mathrm{a}$ & $12 \mathrm{a}$ & $50.67 \mathrm{a}$ & $37.3 \mathrm{a}$ & Silt clay loam \\
Non-conserved & $1.5 \mathrm{a}$ & $42.8 \mathrm{a}$ & $17.8 \mathrm{a}$ & $27.67 \mathrm{a}$ & $36 \mathrm{a}$ & $36.3 \mathrm{a}$ & Clay loam \\
LSD & 0.28 & 9.15 & 7.47 & 18.64 & 15.97 & 15.11 & \\
CV in \% & 4.64 & 5.7 & 11.13 & 26.7 & 10.49 & 11.67 & \\
\hline
\end{tabular}

Mean values followed by the letter "a" is for conserved and non-conserved land statistically not different at $P \leq 0.05$

Table 9 Soil structure description of soil samples from the two treatments

\begin{tabular}{lllllll}
\hline Structure & A & B & C & X & Y & Z \\
\hline Shape/type & Granular & Sub angular blocky & Granular & Sub angular blocky & Blocky & Sub angular blocky \\
Size & Fine & Medium & Medium & Medium & Medium & Medium \\
Grade & Moderate & Moderate & Strong & Moderate & Moderate & Moderate
\end{tabular}

$A, B$, and $C$ were replicated from conserved and $X, Y$ and $Z$ were replicated from non-conserved areas within the watershed

A soil with a well-developed structure has a significant proportion of large pores that promotes aeration and accommodates infiltrating water, resulting in reduced erosion due to decreased runoff (Table 8). The soil in site A, B, and C were described as having a "moderately developed, fine, granular structure"; moderately developed, medium, subangular blocky structure, and strongly developed, medium, granular structure respectively in the conserved areas. The soil in site $\mathrm{X}, \mathrm{Y}$ and $\mathrm{Z}$ was described as having a "Moderately developed, medium, subangular blocky structure"; moderately developed, medium, blocky structure and moderately developed, medium, subangular structure in the non-conserved area within the watershed (Table 9). Similar result was reported by Wheaton. ${ }^{47}$ The granular structure was the result of soil conservation fostering the presence of root in conserved areas (A and C) in Table 9.

Granular or columnar structure may be obtained due to the effect of conservation, while blocky or sub angular blocky structure may be expected in case of soil erosion. ${ }^{48}$ However, the result indicated that there was no great difference between conserved and non-conserved areas in terms of size (except site A, and C), shape, and grade of the structure. Long period of time is required to see changes in soil structure, whereas in the short term (e.g. fiveyears), the effects of erosion and conservation on structure-forming/disappearing may be small. $^{49}$

\section{Conclusion}

The mean annual soil loss rates of the conserved and nonconserved landscapes using RUSLE were 25.59tons/ha/yr and 30.92 tons $/ \mathrm{ha} / \mathrm{yr}$, respectively. This variation may occur due to the scale effect since runoff and soil loss rates from smaller areas are expected to be large. The result from RUSLE depicts that rainfall factor $(\mathrm{R})$, conservation management factor $(\mathrm{P})$ and land use factor (C) were the most dominant factor to contribute soil erosion. 
Soil physical property analysis between the two treatments did not show a statistically significant difference at $p \leq 0.05$ confidence level using LSD. This is due to the inherent property of soil physical properties that need long-term (greater than 5-7years) erosion or conservation duration to change significantly. Generally, irrespective of the numerical variation, soil loss rates in both methods coupled with farmers' real perception has confirmed the soil loss in both treatments cannot be tolerated. Therefore, critical effort to reduce soil erosion in the study watershed is mandatory. Moreover, researchers should focus on the extent of years of conservation and erosion that can significantly affect the changes in the physical properties of soils. ${ }^{50-57}$

\section{Acknowledgements}

None.

\section{Conflict of interest}

Authors declare there is no conflict of interest.

\section{References}

1. Parveen R, Kumar U. The integrated approach of universal soil loss equation and geographical information system (GIS) for soil loss risk assessment in upper south Koel Basin. Jharkhand Journal of Geographic Information System. 2012;4(6):588-5960.

2. Hurni H, Bantider A, Herweg K, et al. Landscape transformation and sustainable development in Ethiopia, background information for a study tour through Ethiopia. compiled by the participants, Centre for Development and Environment, University of Bern; 2006:4-20.

3. Hurni H. L and degradation, famine, and land resource scenarios in Ethiopia. In: Pimentel D editor. World soil erosion and conservation. Cambridge University Press; 1993:27-61.

4. Valera CA, Valle JRF, Varandas SGP, et al. The role of environmental land use conflicts in soil fertility: A study on the Uberaba River basin. Sci Total Environ. 2016;562:463-473.

5. Tenberg A, Da Veiga M, Dechen SCF, et al. Modeling the impact of erosion on soil productivity: a comparative evaluation of approaches on data from southern Brazil. Exp Agr. 1998;34(01):55-71.

6. Girum Woldegiorgis, Masresha Fetene. Assessment of soil erosion hazard in kilie catchment, east shoa, Ethiopia. Land Degrad Development. 2012;23:293-306.

7. Chimdi A, Heluf Gebrekidan, Kibebew Kibret, et al. Tadesse. 2012. Effects of liming on acidity-related chemical properties of soils of different land use systems in Western Oromia, Ethiopia. World J Agric Sci. 2012;8(6):560-556.

8. Teklu Erkossa. L and preparation methods and soil quality of a Vertisols area in the central highlands of Ethiopia. Ph.D. Thesis, Hohenheimer Boden kund liche. Heft 76, Stuttgart: University of Hohenheim; 2005. $133 \mathrm{p}$.

9. Behailu Bezabih, Abebayehu Aticho, Tadesse Mossisa, et al. Journal of soil science and environmental management the effect of land management practices on soil physical and chemical properties in Gojeb sub-river Basin of Dedo District; 2016.

10. Hui L, Xiaoling C, Lim KJ, et al. Assessing soil erosion and sediment yield in Liao watershed, Jiangxi Province, China, Using USLE, GIS, and RS. Journal of Earth Science. 2010;21(6):941-953.

11. Hurni H. Erosion-Productivity-Conservation Systems in Ethiopia. Soil Conservation Research Project (SCRP). In Plasentis I editor. Soil Conservation and Productivity. Proceedings IV International Conference on soil conservation, Maracay, Venezuela; 1985.

12. Prasannakumar V, Vijith H, Abinod S, et al. Estimation of soil erosionrisk within a small mountainous sub-watershed in Kerala, India, using revised universal soil loss equation (RUSLE) and geo-information technology. 2012;3(2):209-215.

13. Alexakis D, Hadjimitsis D, Agapiou A. Integrated use of remote sensing, GIS and precipitation data for the assessment of soil erosion rate in the catchment area of "Yialias" in Cyprus. Atmos Res. 2013;131:108-124

14. Shabani F, Kumar L, Esmaeili A. Improvement to the prediction of the USLE K factor. Geomorphology. 2014;204:229-234.

15. DSA (Development Studies Associates) and SCI (Shawel Consult International). The potential survey, Identification of opportunities and preparations of projects profiles and feasibility studies. Ethiopia: Addis Ababa; 2006.

16. Nekhay O, Arriaza M, Boerboom L. Evaluation of soil erosion risk using Analytic Network Process and GIS: a case study from Spanish mountain olive plantations. J Environ Manage. 2009;90(10):3091-3104

17. Y1lman F. "Predicting Soil Loss in the catchments of Eldivan SarayköyII Dam (Çankırı), By the RUSLE Methodology”, M. Sc. thesis, Ankara University; 2009.

18. Abubaker HM, Elhag AMH, Salih AM. Accuracy Assessment of Land Use and Land Cover Classification (LU/LC). Case study of Shomadi area-Renk County-Upper Nile State, South Sudan. International Journal of Scientific and Research Publications. 2013;3:5.

19. Tadesse Amsalu, Abebe Mengaw. GIS-based soil loss estimation using RUSLE Model: the case of Jabi Tehinan District, ANRS. Ethiopia. Natural Resour. 2014;5:616.

20. Atesmachew Bizuwerk, Girma Taddese, Yasin Getahun. Application of GIS for Modeling Soil loss rate in Awash River Basin, Ethiopia international Livestock Research Institute (ILRI), P.o.Box 5689. Ethiopia: Addis Ababa; 2010.

21. Wischmeier WH, Smith DD. Predicting rainfall erosion losses: A guide to Conservation planning. U.S. Department of Agriculture. Agriculture Handbook No. 537, Washington DC., US. Government Printing Office; 1978.

22. Gee GW, Bauder JW. Particle-size analysis. In A. Klute editor. Methods of soil analysis. Part 1. 2nd ed. Agron. Monogr. 9. ASA and SSSA, Madison; 1986:383-411.

23. Blake GR, Hartge KH. Bulk density. In: A Klute, editor. Methods of soil analysis. Part 1.2nd ed. Agron. Monogr. 9. ASA and SSSA, Madison, WI. 1986.363 p.

24. Black CA. Methods of soil analysis. Part I, American Society of Agronomy. Madison, Wisconsin, USA; 1965. 1572 p.

25. Brady NC, Weil RR. The nature and properties of soils. 11th ed. New York: Prentice Hall; 1996.

26. Dabral PP, Baithuri N, Pandey A. Soil erosion assessment in a hilly catchment of North Eastern India using USLE, GIS, and remote sensing. Water Resources Management. 2008;22(12):1783-1798.

27. Pauwels JM, Aelterman J, Gabriels D, et al. Soil erodibility map of Belgium; 1980. $195 \mathrm{p}$.

28. Morgan RPC. Soil Erosion and Conservation. 3rd ed. Malden, Mass; 2005 .

29. Gizachew Ayalew. A geographic information system based soil loss and sediment estimation in Zingin watershed for conservation planning, Highlands of Ethiopia. World Appl Sci J. 2015;33(1):69-79

30. Solomon Hishe, Lyimo J, Woldeamlak Bewket. Effects of soil and water conservation on vegetation cover: a remote sensing based study in the Middle Suluh River Basin, northern Ethiopia. Environmental Systems Research. 2017;6:26.

31. Amare Sisay, Nega Chalie, Zenebe Girmay, et al. Landscape-scale soil 
erosion modeling and risk mapping of mountainous areas in eastern escarpment of Wondo Genet watershed, Ethiopia. 2014.

32. Gelagay Habtamu, Amare Sewnet. Soil loss estimation using GIS and Remote sensing techniques: a case of Koga watershed, Northwestern Ethiopia. Int Soil Water Conserved. 2016;4(2):126-136.

33. Temesgen Gashaw, Tafa Tulu, Mekuria Argaw. Erosion risk assessmen for prioritization of conservation measures in Geleda watershed, Blue Nile basin, Ethiopia. Environmental Systems Research. Ethiopia: Addis Ababa University; 2017.

34. Mati BM, Morgan RPC, Gichuki FN, et al. Assessment of erosion hazard with the USLE and GIS: A case study of the Upper Ewaso Ng'iro North basin of Kenya. JAG. 2000;2(2):1-9.

35. Kebede Wolka, Mesele Negash. Farmers'Adoption of Soil and Water Conservation Technology: A Case Study of the Bokole and Toni SubWatersheds, Southern Ethiopia. Journal of Science \& Development. 2014;2(1).

36. Herweg K, Ludi E. The performance of selected soil and water conservation measures case studies from Ethiopia and Eritrea, Catena. 1999;36:99-114.

37. Haweni Habtamu. Effect of soil and water conservation on selected soil Characteristics in Dimma watershed, central Ethiopia. 2015.

38. Yihenew G Selassie, Tadele Amare, Aemro Terefe, et al. Soil Properties and Crop Yields along the Terraces and Topo sequece of Anjani Watershed Central Highlands of Ethiopia. 2013;5(2).

39. Demelash Mulugeta, Stahr, K. Assessment of integrated soil and water conservation measures on key soil properties in South Gonder, NorthWestern Highlands of Ethiopia. 2010.

40. Abay Challa, Abdu Abdelkader, Tefera Mengistu. Effects of Graded Stone Bunds on Selected Soil Properties in the Central Highlands of Ethiopia. Int J Nat Res Ecol Manag. 2016;1(2):42-50.

41. Jamala GY, Oke DO. Soil organic carbon fractions as affected by land use in the Southern Guinea Savanna ecosystem of Adamawa State, Nigeria. Journal of Soil Science and Environmental Management. 2013;4(6):116-122

42. Daniel Mengistu, Woldeamlak Bewket, Lal, R. Conservation Effects on Soil Quality and Climate Change. Land Degradation and Development. $2015 ; 27(6)$

43. Amusan AA, Shitu AK, Makinde WO, et al. Assessment of changes in selected soil properties under different land use in Obafemi Awolowo University Community, ILEIFE, Nigeria. Electron J Environ Agric Food Chem. 2006;5(1):1178-1184.

44. ArévaloGardini E, Canto M, Alegre J, et al. Changes in Soil Physical and Chemical Properties in Long-term Improved Natural and Traditional Agroforestry Management Systems of Cacao Genotypes in Peruvian Amazon. PLoS one. 2015;10(7):e0132147.
45. Jay D, Upendra M, William B, et al. Long-term tillage influences on soil physical properties under dryland conditions in north eastern Montana. Agricultural Research Service. United States Department of Agriculture. Archives of Agronomy and soil Science. 2009;55(6):633-640.

46. Mihrete Getnet. Effect of Soil Conservation Structures on some physicochemical Properties of Soil and Crop Yield in Simada District, South Gonder Zone. M. Sc. Thesis. School of Graduate Studies, Haramaya University, Ethiopia; 2014.

47. Wheaton M, Cromer K, Lasalle-Ricci VH, et al. Characterizing the soil structure and its aggregate stability. Environmental monitoring and assessment. 2008;28.

48. Williams ND, Petticrew EL. Aggregate stability in organically and conventionally farmed soils. Soil Use Manage. 2009;25:284-292.

49. Xie JY. Soil aggregation and aggregate associated organic carbon and total nitrogen under long-term contrasting soil management regimes in loess soil. J Integr Agr. 2015;14(12):2405-2416.

50. Brady NC, Weil RR. The nature and properties of soils. 13th ed. New Jersey: Prentice-Hall Inc; 2002.960 p.

51. G'omez FD. Hydrological, eco-physiological and sediment processes in a coffee agroforestry basin: combining experimental and modeling methods to assess hydrological environmental services. Hydrological Earth System Science. 2010;15.

52. Hengsdijk H, Meijerink GW, Mosugu ME. Modeling the Effect of Three Soil and Water Conservation Practices in Tigray, Ethiopia. Agriculture, Ecosystems and Environment. 2005;105(1-2):29-40.

53. Ludi E. Economic analysis of soil conservation: case studies from the highlands of Amhara region, Ethiopia. Geographical bernensia African studies series A18, Institute of Geography, Bern, Switzerland; 2004

54. Rodrigo J, Brings C, Lassu T, et al. Rainfall and human activity impacts on soil losses and rill erosion in vineyards (Ruwer Valley, Germany). Solid Earth. 2015;6:823-837.

55. Shimeles Damene. The effectiveness of soil and water conservation measures for land restoration in the Wello area, northern Ethiopian highlands. Dissertation. 2012.

56. Worku Hailu. Impact of Physical Soil and Water Conservation Structure on Selected Soil Physicochemical Properties in Gondar Zuriya district. Department of Water Resources and Irrigation Management, Ambo University, Ambo, Ethiopia. Resources and Environment. 2017;7(2):40-48.

57. Xu Y, Shao X, Kong X, et al. Adapting the RUSLE and GIS to Mode soil erosion risk in a mountain carst watershed, Guizhou province, China. Environmental monitoring and assessment. 2008;141(1-3):275-286. 